\title{
CSAPADÉKMEZŐK MINTÁZATÁNAK ÉS SZÉLSŐSÉGEINEK VÁLTOZÁSA EURÓPA DÉLI TÉRSÉGEIBEN
}

\author{
Berényi Alexandra (D), Pongrácz Rita (D), Bartholy Judit \\ ELTE Meteorológiai Tanszék, 1117 Budapest, Pázmány Péter sétány 1/A \\ e-mail: berenyia@caesar.elte.hu,prita@nimbus.elte.hu,bartholy@caesar.elte.hu
}

\section{Bevezetés}

A klímaváltozás napjaink egyik legfontosabb globális problémája, éppen ezért egy sokat kutatott témakör. Ezen belül is kiemelkedik a csapadékmezők vizsgálata, ugyanis a hőmérséklet emelkedésével nőhet a légkör vízgőztartalma, ez pedig közvetlen hatással van a csapadékos helyzetekre is. Míg a globális hőmérséklet egyértelmü növekvő tendenciát mutat a mérések alapján, addig a csapadék nagyobb időbeli és térbeli változékonysága miatt a változás mértéke és iránya eltérő az egyes régiókban. Még Európán belül sem egységes a csapadékmezők változásának trendje. Modellszimulációk eredményei alapján a kontinens északi régiói csapadékosabbá, míg a déli területek szárazabbá válnak a XXI. század végére (Jacob et al., 2014). Az átlagos csapadékmennyiség változása mellett azonban az egész kontinensen várható a szélsőséges csapadékos helyzetek számának, illetve intenzitásának növekedése, amelyek önmagukban is komoly természeti kockázatot jelentenek, de magukkal vonhatják árvizek, villámárvizek kialakulását is (Rajczak \& Schär, 2017). A kontinens déli részén pedig nem csak a csapadékos helyzetek szélsőségek felé tolódása jelenthet a jövőben problémát, hanem a száraz időszakok gyakoriságának és hosszának növekedése is (Jacob et al., 2014).

Számos kutatás és tanulmány mutatja, hogy a csapadékmezőkben várhatóan bekövetkező változások, vagyis az extrém csapadékos és extrém száraz helyzetek gyakoriságának növekedése már az utóbbi néhány évtizedben is kimutatható. A kontinens déli területeit érintő várható jövőbeli változások mértékét szem elött tartva ebben a tanulmányban három, Európa déli területein elhelyezkedő alföldi terület (amelyek közül egyik a magyar Alföld területét is magában foglalja) múltra vonatkozó vizsgálatát mutatjuk be, melyek esetében a klímaváltozás következményei jelentős hatást gyakorolhatnak a gazdaságra, a társadalomra és a környezetre egyaránt.

\section{E-OBS adatbázis és a területek kiválasztása}

A múltra vonatkozó éghajlati elemzésünket az E-OBS (Cornes et al., 2018) 20. verziójának felhasználásával készítettük el, amely szabályos rácsra interpolált meteorológiai adatokat tartalmaz egész Európára 1950-től napjainkig napi időbeli felbontással. Az adatbázis $0,1^{\circ}$-os és $0,25^{\circ}$-os térbeli felbontásban elérhető mezői közül mi a $0,1^{\circ}$-os csapadékmezőt használtuk fel a csapadék nagy időbeli és térbeli változékonysága miatt.

Mivel a mezőgazdaság szempontjából kiemelt fontosságúak a sík területek, illetve a világ lakosságának jelentős része alföldi területeken él, ezért a kutatásunk során alföldi területeket választottunk ki az éghajlati elemzéshez. Az alföldeket egy általunk összeállított objektív feltételrendszer segítségével definiáltuk, nevezetesen az egyes régióknak két kritériumnak kellett megfelelnie:

1. A tengerszint feletti magasság nem haladhatja meg a 200 métert. Tekintve, hogy a felföldek sajátos éghajlati viszonyokkal rendelkezhetnek, a csapadékmező mintázata, az extrémumok és az időbeli változások jelentősen eltérhetnek az alacsonyabban fekvő térségektől. 
2. A tengerszint feletti magasság régión belüli változásának mértéke nem haladhatja meg az 50 métert. Ebben az esetben a közvetlen szomszédos cellákat vettük figyelembe.

Az így kapott európai területek határait nagyrészt a geográfiai határok alapján választottuk meg. A 14 európai régió közül az itt kiválasztott három régió: a Pó-síkság (PVL), a Pannon-alföld (PNP) és a Román-alföld (RMP), melyek elhelyezkedése és kiterjedése az 1. ábrán látható.

A csapadékmezők részletes elemzéséhez és a szélsőségek vizsgálatához klímaindexeket használunk. A klímaindexeket széleskörüen alkalmazzák az éghajlati vizsgálatokban (pl.: Klein Tank \& Können, 2003) és a modellvalidációkban egyaránt. Az ETCCDI ${ }^{1}$ (Peterson et al., 2001) 11 csapadékra vonatkozó indexéből hetet használtunk fel, illetve meghatároztunk további 10 indexet, amelyeket az 1. táblázatban foglalunk össze.
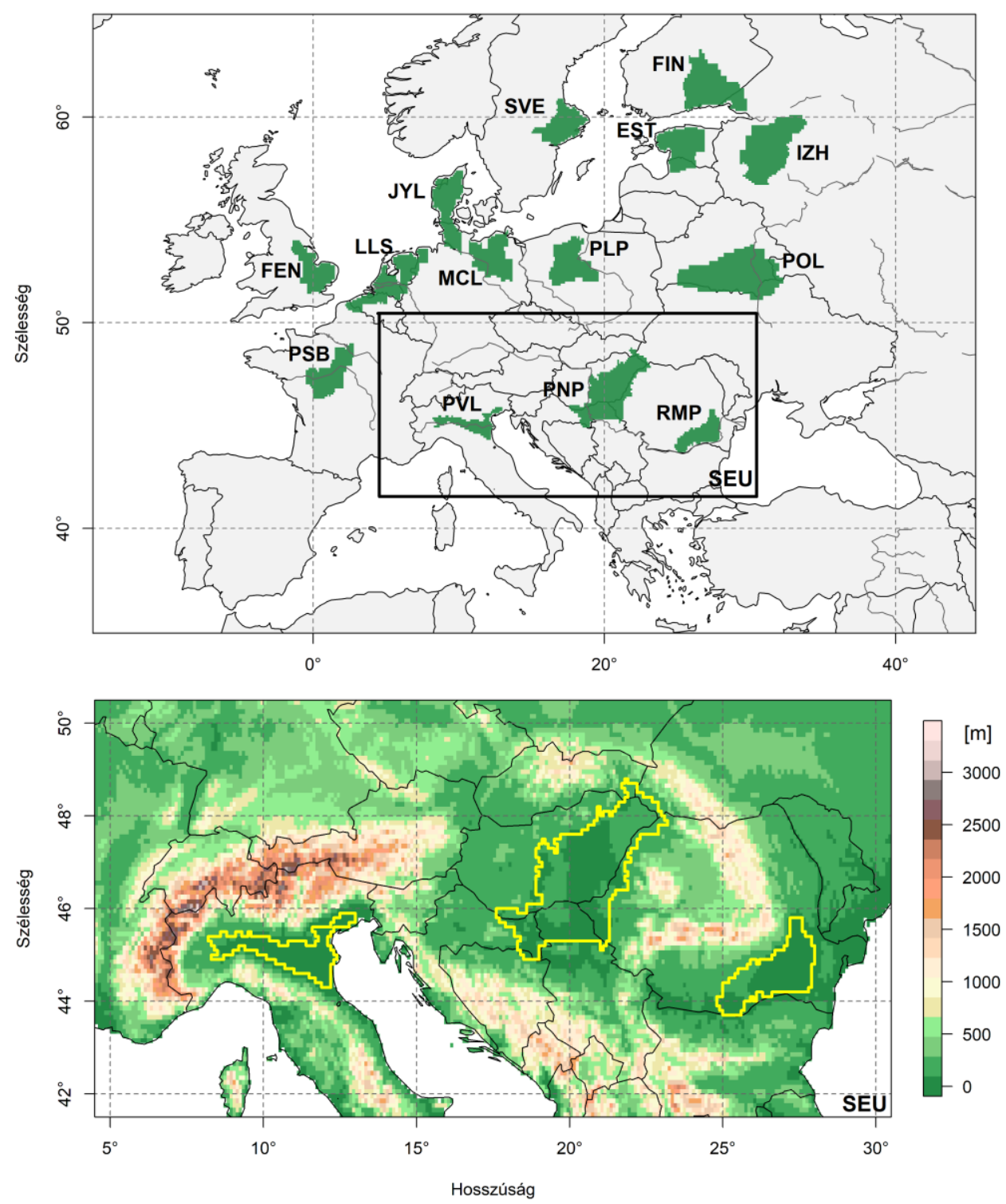

1. ábra: A 14 kiválasztott alföldi régió elhelyezkedése Európán belül (fent), és az ebben a tanulmányban vizsgált három régió domborzati viszonyai (lent).

\footnotetext{
${ }^{1}$ Expert Team on Climate Change Detection and Indices: Szakértői csoport az éghajlatváltozás detektálására és a klímaindexekkel kapcsolatban
} 
1. táblázat: A kutatás során számított klimatológiai indexek rövidítése és definíciója.

\begin{tabular}{|c|c|c|}
\hline Index & Leírás & Mértékegység \\
\hline RR1 & 1 mm-t meghaladó csapadékú napok száma (Rnap $\geq 1 \mathrm{~mm})$ & nap \\
\hline RR5 & 5 mm-t meghaladó csapadékú napok száma (Rnap $\geq 5 \mathrm{~mm}$ ) & nap \\
\hline RR10 & Nagy csapadékú napok száma (Rnap $\geq 10$ mm) & nap \\
\hline RR20 & Extrém csapadékú napok száma (Rnap $\geq 20$ mm) & nap \\
\hline RX1 & Legnagyobb 1 napi csapadékösszeg (Max (Rnap)) & $\mathrm{mm}$ \\
\hline RX5 & $\begin{array}{l}\text { Legnagyobb } 5 \text { napos csapadékösszeg } \\
\left(\operatorname{Max}\left(\operatorname{Rnap}_{i, i+1, i+2, i+3, i+4))}\right.\right.\end{array}$ & $\mathrm{mm}$ \\
\hline R90p & Napi csapadékösszegek 90. percentilise & $\mathrm{mm}$ \\
\hline $\mathrm{R} 95 \mathrm{p}$ & Napi csapadékösszegek 95. percentilise & $\mathrm{mm}$ \\
\hline $\mathrm{R} 95 \mathrm{~N}$ & $\begin{array}{l}\text { Csapadékos napok csapadékösszegének 95. percentilisét } \\
\text { meghaladó napok száma }\end{array}$ & nap \\
\hline PRCPTOT & Éves csapadékösszeg & $\mathrm{mm}$ \\
\hline SDII & $\begin{array}{l}\text { Csapadékintenzitás index: a csapadékos napokon hulló } \\
\text { átlagos csapadék. }\end{array}$ & $\mathrm{mm} / \mathrm{nap}$ \\
\hline CDD & Egymást követő száraz napok maximális száma & nap \\
\hline DD & $\begin{array}{l}\text { Száraz napok száma, amikor a csapadék nem haladja meg } \\
\text { az } 1 \mathrm{~mm}-\mathrm{t} \text { (Rnap }<1 \mathrm{~mm})\end{array}$ & nap \\
\hline DS5 & Az 5 napot meghaladó száraz időszakok száma & - \\
\hline DS10 & A 10 napot meghaladó száraz időszakok száma & - \\
\hline DS95p & $\begin{array}{l}\text { Az } 5 \text { napnál hosszabb száraz időszakok hosszának } 95 . \\
\text { percentilise }\end{array}$ & nap \\
\hline DS5N & Napok száma az 5 napot meghaladó száraz időszakok során & nap \\
\hline
\end{tabular}

A számított klímaindexeket több csoportba sorolhatjuk:

Rögzitett küszöbértéket alkalmazó indexek: Ide tartoznak azok az indexek, amelyek egy rögzített érték meghaladását veszik alapul. Ezek az indexek jelentősen eltérhetnek az egyes területek esetében, mivel az adott térség klimatológiai jellemzőitől nagymértékben függenek. Éppen ezért ezek az indexek alkalmasak az egyes térségek, éghajlati típusok elkülönítésére és a területi különbségek feltárására. A vizsgálatok során öt ilyen típusú indexet határoztunk meg: RR1 (csapadékos napok száma), RR5, RR10, RR20 (a számérték jelzi az alkalmazott küszöbértéket mm-ben) és DD (száraz napok száma).

Percentilis alapú indexek: Azokat az indexeket soroljuk ebbe a kategóriába, amelyek valamelyik percentilishez tartozó értéket adnak vissza, illetve meghaladnak egy hosszútávú percentilis alapú küszöbértéket. Elemzéseinkben ilyen indexek az R90p és az R95p, amelyek a napi csapadék idősorának rendre a 90., illetve a 95. percentilise; az R95N, amely azon napok számát adja meg, amelyek meghaladják a napi csapadékmennyiség 95 . percentilisét a teljes idősorra vonatkoztatva; valamint a DS95p, ami az öt napot meghaladó száraz időszakok hosszának 95. percentilise.

Extrém értékeken alapuló indexek: Az egyes időszakok - éves vagy évszakos - során előforduló maximum értékek. A csapadékos napokhoz köthető indexek: az egy, illetve öt nap alatt lehullott csapadékösszegek maximum értéke (rendre RX1, illetve RX5), továbbá a száraz időszakokhoz kapcsolódik az egybefüggő száraz napok maximális hossza (CDD). 
Egyéb indexek: A vizsgálat során felhasználtuk a csapadékos napok éves csapadékösszegét (PRCPTOT), illetve az ebből számított ún. egyszerü, napi csapadékintenzitási indexet (SDII), amely az adott időszakban - itt éves időtartamban - a csapadékösszeg és a csapadékos napok hányadosa. Kiszámítottuk továbbá az öt, illetve tíz napnál hosszabb száraz időszakok előfordulásának számát az egyes évszakokra (DS5 és DS10), valamint az öt napnál hosszabb száraz időszakok során előforduló napok számát (DS5N) is.

\section{A régiók területi változékonysága}

Az alföldi régiók kiválasztásánál ügyeltünk arra, hogy Európa minél nagyobb részét lefedjük, és a területek reprezentálják a kontinensen megtalálható éghajlati osztályokat, amennyiben ez lehetséges. A 14 régió közül a négy nyugat-európai területet óceáni éghajlat jellemzi, Észak-Európa négy régiójában a tajga és a nedves kontinentális az uralkodó éghajlat, míg a Kelet- és Közép-Európa északi részén lévő három régió nedves kontinentális éghajlaton helyezkedik el. A tanulmányunk középpontjában lévő három déli terület közül a Pannon-alföld és a Román-alföld éghajlati besorolása kontinentális hosszabb meleg évszakkal, míg a Pó-síkság a mediterrán térségben szubtrópusi éghajlattal rendelkezik.
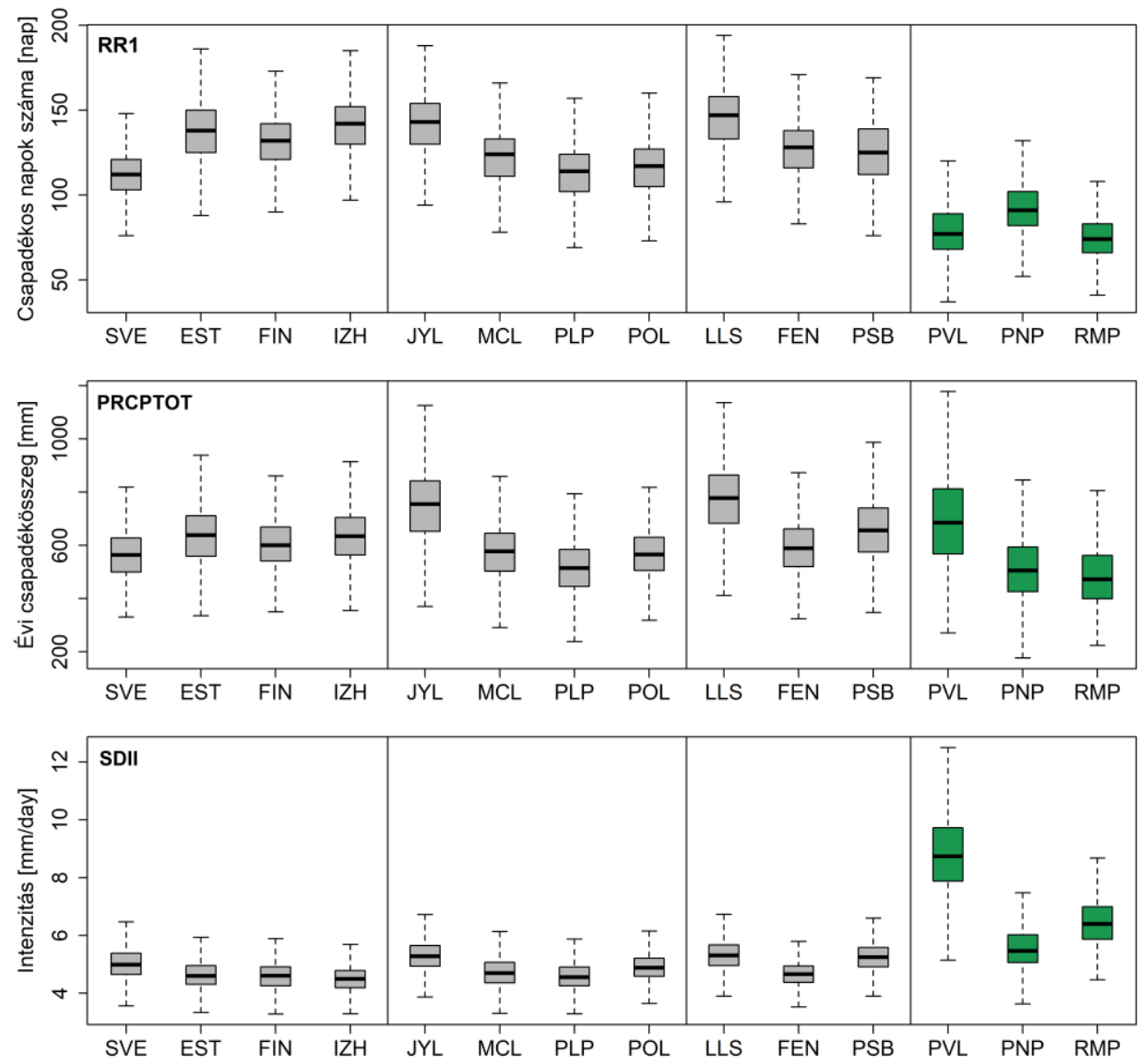

2. ábra: Az RR1, PRCPTOT és SDII indexek rácsponti idősorainak területenkénti eloszlása

(a szaggatott függőleges vonalak jelölik a minimum és a maximum közötti intervallumot, a szélesebb téglalapok az alsó és felső kvartilis közötti tartományt, a vastag fekete vonalak pedig a mediánt jelölik). A területek nyugatról keletre, majd északról délre vannak a diagramon elhelyezve. 
A 2. ábra jól szemlélteti a 14 régió általános csapadékviszonyai közötti különbségeket. A kontinentális hatásból fakadóan a kontinens belseje felé haladva csökken a csapadékos napok száma és az éves csapadékösszeg. A három déli terület csapadékos napjainak száma láthatóan jelentősen elmarad a többi területétől. Az éves csapadékösszegben már nem mutatkoznak ekkora eltérések. Ez tehát azt eredményezi, hogy a két indexből származtatott SDII értékei magasabbak a déli régiókban, mint a kontinens többi részén.

A magasabb napi csapadékintenzitás arra enged következtetni, hogy a három térségben a csapadékos napok során többször következik be extrém csapadékos helyzet. Ezt erősíti meg a 3. ábra (a)-(c) része, amin rendre az RR5, RR10 és RR20 látható az RR1 függvényében. A diagramokon is látható, hogy majdnem minden esetben a három déli terület jelentősen eltér az északi területektől: kevesebb csapadékos napra közel hasonló mértékü vagy magasabb számú extrém csapadékos nap jut. Kiemelhető ebből a szempontból a Pó-síkság, ahol az alacsony számú csapadékos napok mellett rendre a legmagasabb számú szélsőséges csapadékos helyzetek következnek be.
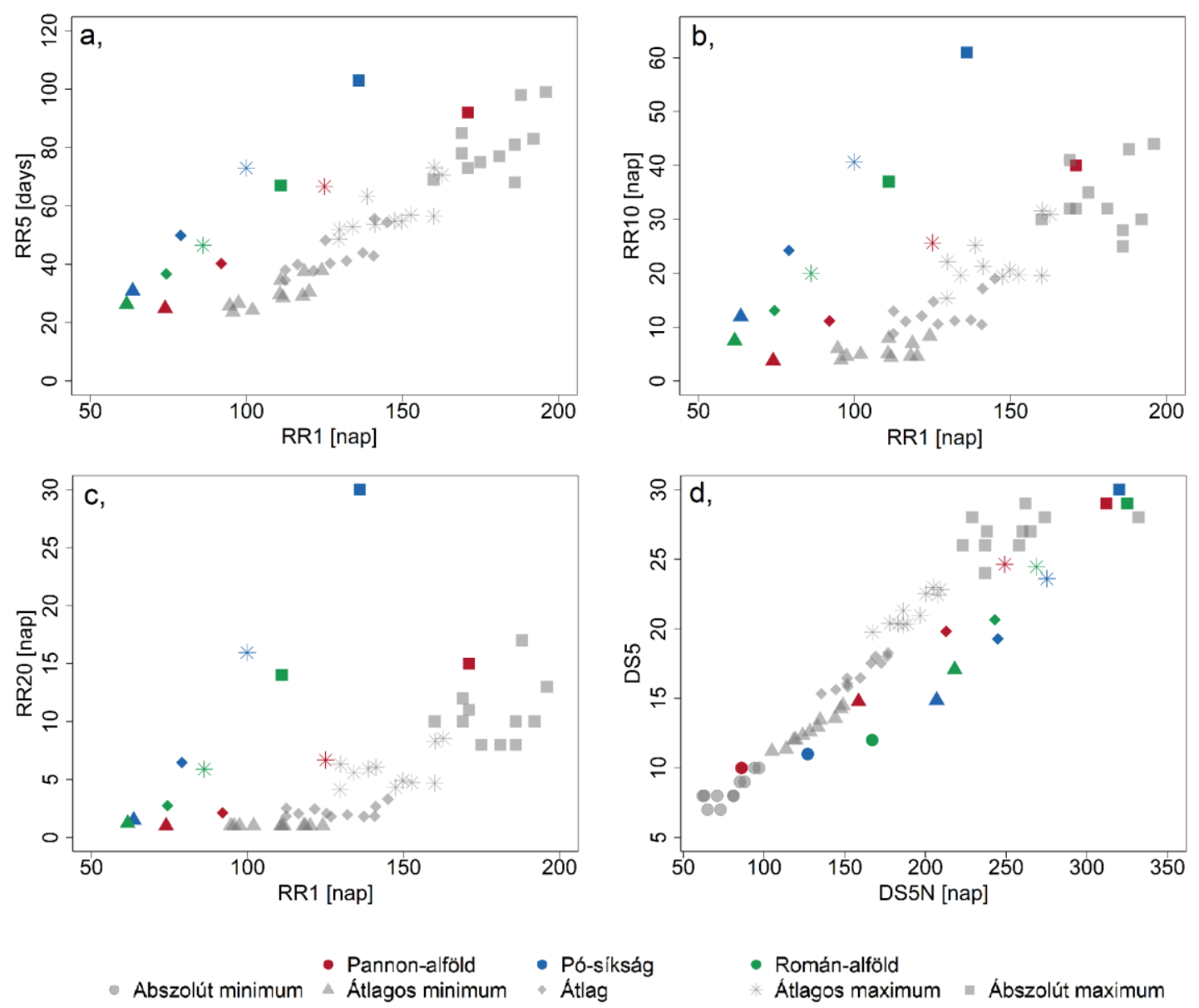

3. ábra: Az RR5, RR10 és RR20 index értéke az RR1 függvényében (a-c) és a DS5 száraz időszakok gyakorisága a DS5N függvényében (d).

Érdemes azt is megjegyezni, hogy egyre intenzívebb csapadékos napokat tekintve a minimumok és az átlagok értéke fokozatosan csökken. Ebből arra következtethetünk, hogy az extrém csapadékos helyzetek a legtöbb esetben csak kis területeket (néhány rácspontot) érintenek egy adott régión belül. Habár az extrém csapadékok tehát jórészt lokális jellegüek, a Pó-síkság magasabb minimumai azt jelzik, hogy szélsőséges helyzetek nagy- 
térségü folyamatokhoz is köthetők. Ezen régió geográfiai adottságai, illetve elhelyezkedése okozhat a térségben kiterjedt szélsőséges helyzeteket. A régió ugyanis közel helyezkedik el a Genovai-öbölhöz, amely a nyugati mediterrán ciklonok keletkezési helyszíne. Ezek a ciklonok hatással lehetnek a vizsgálatunkba bevont másik két déli térségre is, mivel a mediterrán ciklonok általános haladási útvonala (Messmer et al., 2015) mentén találhatók.

A száraz időszakok elemzésekor is hasonló mintázat ismerhető fel. A három déli régió ugyanis ebben az esetben is eltér az északi régióktól, azonban itt az egyes területek között is látunk eltéréseket. A nagyobb számú csapadékmentes nap nem feltétlenül jelent egyben több száraz periódust is, mivel egy extrém hosszú száraz periódus csökkenti az egy évben előforduló száraz időszakok számát.

A 3. ábra (d) részében az 5 napnál hosszabb száraz időszakok számát mutatja az ezekhez tartozó napok összegének függvényében. A három terület száraz napjainak száma magasabb, ugyanakkor a száraz időszakok száma az abszolút és átlagos minimumok, az átlagok és átlagos maximumok esetében is magasabb, ami arra enged következtetni, hogy a száraz időszakok átlagos hossza nem kiemelkedően magas. Az abszolút maximumok esetében minden területen 25 és 30 közötti száraz időszakkal számolhatunk egy évben, azonban a három déli területhez több csapadékmentes nap társul, ami azt jelzi, hogy a régiók bizonyos részein előfordulnak szélsőségesen hosszú száraz időszakok, és azok a három déli terület esetében a legextrémebbek.

\section{A régiók időbeli változékonysága}

Bár Európa általánosan csapadékosabbá vált az elmúlt évtizedekben a kontinensen megfigyelhető egy ellentétes előjelű változás is (pl.: Zolina et al., 2013). Míg az Észak- és Nyugat-Európai területek esetében egyértelmüen növekszik a csapadékösszegek és a csapadékos napok száma, a kontinens déli részén szárazodás figyelhető meg (Spinoni et al., 2017).

A 4. ábrán a csapadékos napok számának és az éves csapadékösszegnek az éves trendje jól szemlélteti az előbb leírtakat: a három déli régió közül kettő esetében (a Pó-síkságon és a Pannon-alföldön) megfigyelhető a csapadékos napok számának csökkenése, ugyanakkor ezzel összefüggésben az éves csapadékösszegek növekvő tendenciát mutatnak, míg a Pósíkság esetében ez a változó szignifikánsan csökkent az utóbbi évtizedekben.
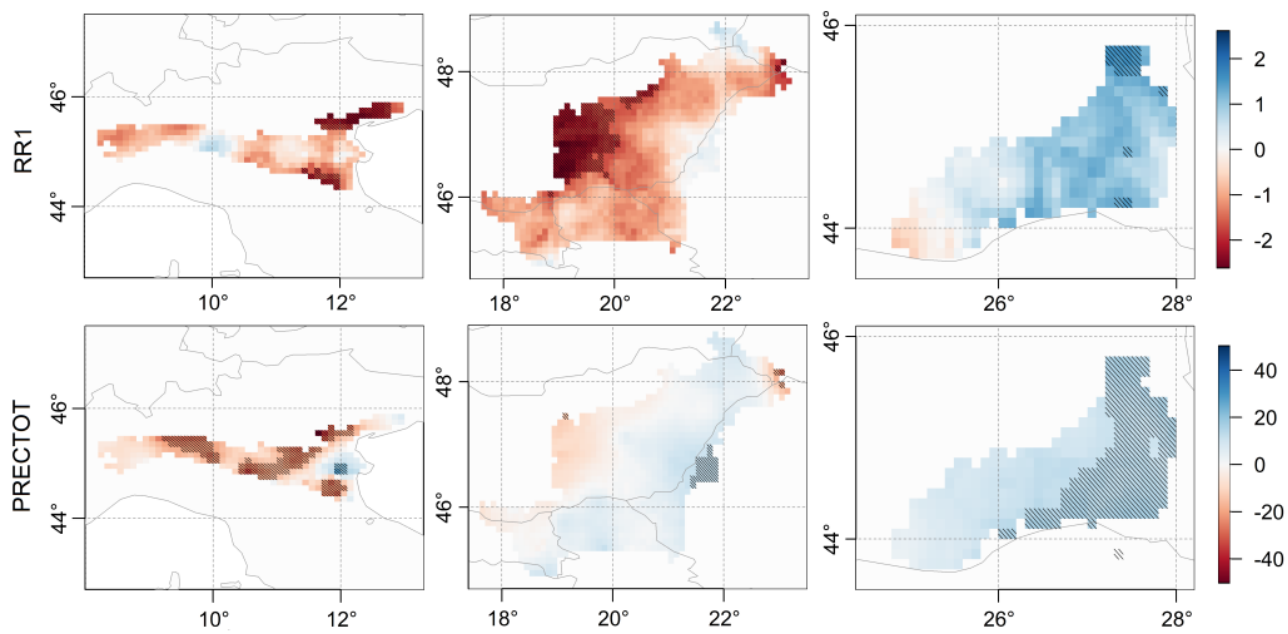

4. ábra: Az RR1 és a PRCPTOT index egyes rácspontokban számított évtizedes trendjeinek összehasonlítása. A vonalkázás szignifikáns változást jelez. 
Habár az éves csapadékösszeggel való összefüggése nem egyértelmü, az SDII szintén csökkenő tendenciát mutat a PVL, és növekvő tendenciát a PNP és az RMP esetében. Ebből arra következtethetünk, hogy az elmúlt évtizedekben a dél-európai régiókban a csapadékos helyzetek intenzitása növekszik, ami pedig az extrém csapadékos helyzetek gyakoriságának növekedését vonhatja maga után.

A 2. táblázat összefoglalja az egyes indexek trendjeit az összes régióban. A Románalföld esetében mind a csapadékos helyzetek előfordulásának gyakorisága, mind pedig az intenzitása növekedő trendet mutat. Tehát a trendek a térség csapadékosabbá válását jelzik, a csapadékos helyzetekkel kapcsolatos indexek esetében a negatív trend csupán pár rácspontban fordul elö, s ezek nem is szignifikánsak.

2. táblázat: Az indexek évtizedes trendegyütthatói az összes térségre. A negatív (kék) és pozitív (piros) értékek a legnagyobb pozitív, illetve negatív trendegyütthatók értékeit mutatják, százalékok pedig a szignifikáns pozitív, illetve negatív trenddel rendelkező cellák arányát mutatja.

\begin{tabular}{|c|c|c|c|c|c|c|c|c|c|c|c|c|}
\hline \multirow{3}{*}{ RR1 } & \multicolumn{4}{|c|}{ PVL } & \multicolumn{4}{|c|}{ PNP } & \multicolumn{4}{|c|}{ RMP } \\
\hline & \multicolumn{2}{|c|}{ negatív trend } & \multicolumn{2}{|c|}{ pozitív trend } & \multicolumn{2}{|c|}{ negatív trend } & \multicolumn{2}{|c|}{ pozitív trend } & \multicolumn{2}{|c|}{ negatív trend } & \multicolumn{2}{|c|}{ pozitív trend } \\
\hline & $-2,43$ & $7 \%$ & 0,77 & $0 \%$ & $-2,61$ & $14 \%$ & 0,70 & $0 \%$ & $-0,74$ & $0 \%$ & 1,62 & $5 \%$ \\
\hline RR5 & $-2,87$ & $29 \%$ & $\mathbf{1 , 5 5}$ & $0 \%$ & $-1,81$ & $1 \%$ & 1,11 & $0 \%$ & $-0,64$ & $0 \%$ & 1,31 & $23 \%$ \\
\hline RR10 & $-1,96$ & $15 \%$ & 1,20 & $1 \%$ & $-1,37$ & $0 \%$ & 1,04 & $24 \%$ & 0,17 & $0 \%$ & $\mathbf{0 , 8 1}$ & $27 \%$ \\
\hline RR20 & $-1,18$ & $2 \%$ & 0,84 & $10 \%$ & $-0,33$ & $1 \%$ & 0,57 & $38 \%$ & 0,00 & $0 \%$ & 0,38 & $36 \%$ \\
\hline $\mathrm{RX} 1$ & $-2,51$ & $0 \%$ & 2,28 & $3 \%$ & $-1,04$ & $0 \%$ & 3,40 & $29 \%$ & 0,04 & $0 \%$ & 1,74 & $15 \%$ \\
\hline RX5 & $-4,34$ & $1 \%$ & 3,76 & $1 \%$ & $-0,79$ & $0 \%$ & 4,21 & $42 \%$ & 0,55 & $0 \%$ & 3,15 & $7 \%$ \\
\hline R90p & $-0,87$ & $2 \%$ & 0,79 & $12 \%$ & $-0,40$ & $1 \%$ & 0,60 & $45 \%$ & 0,04 & $0 \%$ & 0,51 & $25 \%$ \\
\hline R95p & $-1,09$ & $1 \%$ & 1,25 & $14 \%$ & $-0,50$ & $1 \%$ & 0,93 & $36 \%$ & $-0,01$ & $0 \%$ & 0,66 & $35 \%$ \\
\hline $\mathrm{R} 95 \mathrm{~N}$ & $-0,90$ & $1 \%$ & 0,48 & $0 \%$ & $-0,94$ & $0 \%$ & 1,09 & $2 \%$ & 0,00 & $0 \%$ & 0,48 & $3 \%$ \\
\hline PRCPTOT & $-50,29$ & $15 \%$ & 28,13 & $1 \%$ & $-27,56$ & $0 \%$ & 12,16 & $2 \%$ & 3,20 & $0 \%$ & 16,41 & $44 \%$ \\
\hline SDII & $-0,42$ & $17 \%$ & 0,37 & $8 \%$ & $-0,11$ & $0 \%$ & 0,16 & $44 \%$ & 0,02 & $0 \%$ & 0,15 & $14 \%$ \\
\hline DD & $-0,76$ & $0 \%$ & 2,44 & $7 \%$ & $-0,68$ & $0 \%$ & 2,62 & $14 \%$ & $-1,61$ & $1 \%$ & 0,76 & $0 \%$ \\
\hline DS5N & $-1,77$ & $0 \%$ & 3,74 & $4 \%$ & $-1,89$ & $0 \%$ & 5,97 & $26 \%$ & $-3,09$ & $1 \%$ & 1,01 & $0 \%$ \\
\hline DS5 & $-0,41$ & $4 \%$ & 0,14 & $0 \%$ & $-0,34$ & $1 \%$ & 0,41 & $4 \%$ & $-0,18$ & $0 \%$ & 0,35 & $1 \%$ \\
\hline DS10 & $-0,02$ & $0 \%$ & 0,28 & $4 \%$ & 0,02 & $0 \%$ & 0,58 & $58 \%$ & $-0,30$ & $3 \%$ & $-0,01$ & $0 \%$ \\
\hline DS95p & $-0,45$ & $4 \%$ & 0,28 & $0 \%$ & $-0,40$ & $2 \%$ & 0,49 & $7 \%$ & $-0,21$ & $0 \%$ & 0,25 & $0 \%$ \\
\hline CDD & $-0,62$ & $0 \%$ & 1,69 & $0 \%$ & $-1,45$ & $1 \%$ & 1,74 & $2 \%$ & $-1,56$ & $2 \%$ & 0,98 & $0 \%$ \\
\hline
\end{tabular}

A Pannon-alföldön szintén növekedett az extrém csapadékos helyzetek előfordulása és gyakorisága. Ebben a térségben a szignifikáns növekedés már több rácspontot érint, mint a Román-alföld esetében, ugyanis az extrém csapadékos helyzetekhez kapcsolódó indexek közül négy esetben a térség több mint egyharmad része szignifikáns növekedést mutat. A román térséggel ellentétben a Pannon-alföldön a száraz időszakokkal kapcsolatos indexek is növekvő tendenciát mutatnak, amiböl arra következtethetünk, hogy itt a csapadékos helyzetek a szélsőségek felé tolódtak el.

A Pó-síkság kis területe ellenére nem fedezhetünk fel egyértelmü trendet; a régió egyes térségeiben szignifikáns növekedés figyelhető meg, míg más részeken szignifikáns csökkenés. Ez az ellentétes viselkedés az extrém csapadékos indexek esetén mutatható ki leginkább. Míg a percentilis alapú R90p és R95 indexek, illetve az RR20 szignifikánsan növekedtek, addig az RR10 és RR5 csökkentek, ami arra enged következtetni, hogy a 
csapadék itt szintén szélsőséges irányba tolódott el, miközben a nem-extrém csapadékos napok száma csökkent.

Nem csak az extrém csapadékos helyzetek előfordulása növekedett, hanem az extrém száraz időszakok hossza és gyakorisága is (5. ábra). A DS5N index értékei szignifikánsan növekedtek a Pó-síkság és a Pannon-alföld esetében, és csökkentek a Román-alföld esetében, azonban az 5 napot és a 10 napot meghaladó száraz időszakok ellentétes irányú tendenciát mutatnak a régiókon belül.
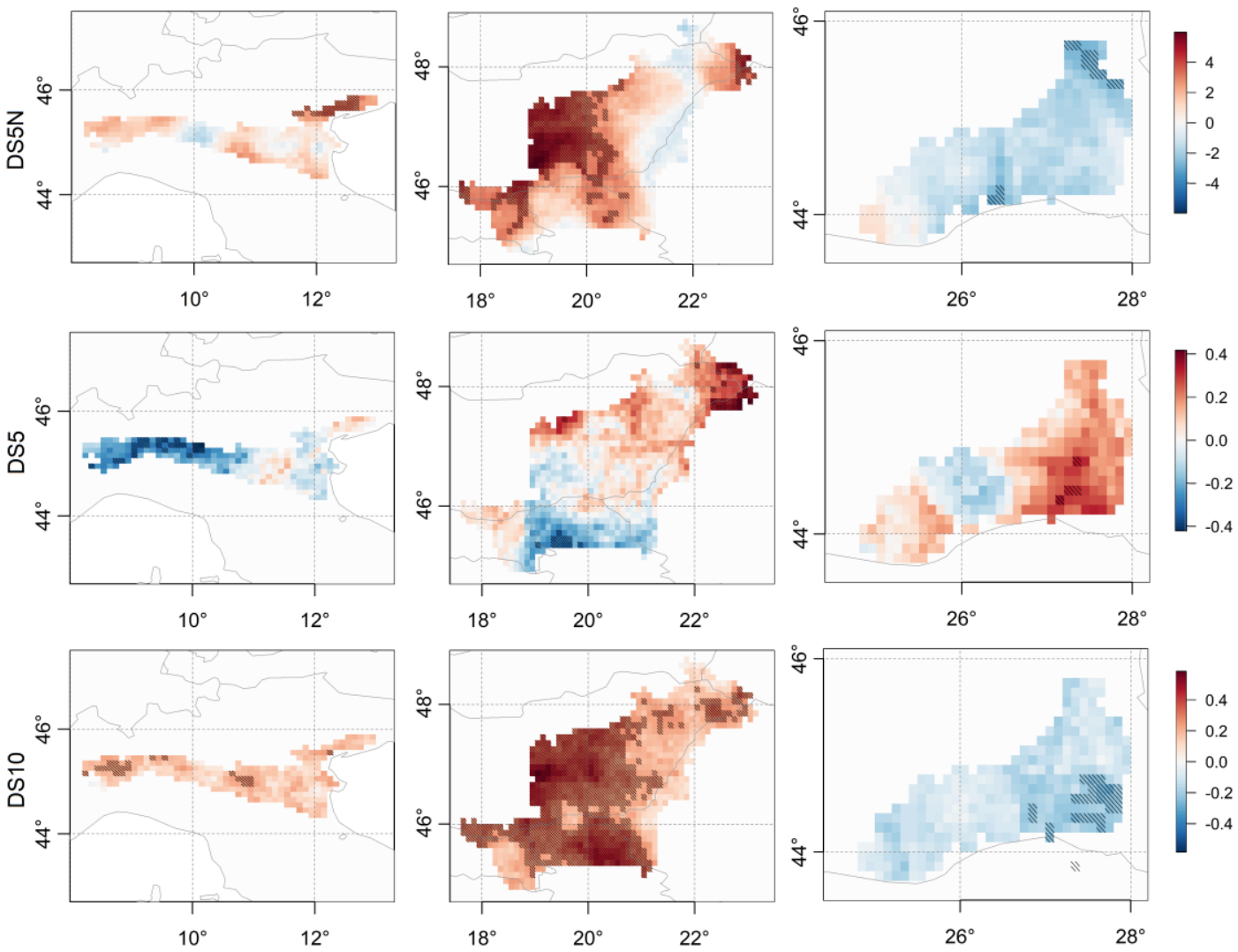

5 ábra: Az DS5N, a DS5 és a DS10 indexek egyes rácspontokban számított évtizedes trendjeinek összehasonlítása. A vonalkázás szignifikáns változást jelez.

Míg a DS10 index az egész területre vonatkozó pozitív trendet mutat a Pó-síkság és a Pannon-alföld esetében és negatív trendet a Román-alföld esetében, addig a DS5 index változása egy területen belül is nagy különbségeket mutat. Ennek oka a DS5 és DS10 indexek felső értékhatárában keresendő, ugyanis egy éven belül csak meghatározott számú száraz időszak fordulhat elő. A 10 napnál hosszabb száraz időszakok növekedése pedig magával vonhatja az 5 napnál hosszabb száraz időszakok csökkenését - tekintve, hogy minél hosszabb egy száraz időszak, annál kevesebb fordulhat elő egy évben.

A romániai régió ebben az esetben is eltér a másik kettő régiótól, ugyanis nem csak a 10 napot meghaladó száraz időszakok száma, de a csapadékmentes napok száma is csökken. Annak ellenére, hogy az 5 napot meghaladó száraz időszakok száma növekvő tendenciát mutat, a másik kettő indexszel összevetve inkább a csapadékosabbá válás jelei mutatkoznak. 


\section{Összefoglalás}

Az általunk vizsgált három déli alföldi régióra kapott eredményeink összhangban vannak az ugyanezen térségeket elemző korábbi tanulmányokban olvasható konklúziókkal. A Román-alföldön a csapadékviszonyok lokális vizsgálata azt mutatja, hogy az éghajlat csapadékosabbá vált, ami egyezik Croitoru et al. (2015) eredményeivel, nevezetesen kimutatták az extrém csapadékos helyzetek előfordulásának növekedését, melyek sokkal inkább kötődnek különálló extrém csapadékos napokhoz, mintsem hosszabb egybefüggő csapadékos periódusokhoz.

A Kárpát-medence térségére készített vizsgálat során Bartholy \& Pongrácz (2007) szintén az extrém csapadékos helyzetek trendjének növekedését mutatta ki a csapadékos napok csökkenése mellett. Eredményeik egybehangzóak azzal a megállapításunkkal, hogy a Pannon-alföld térségében a csapadékos helyzetek száma csökkent és eltolódott a szélsőségek felé az extrém csapadékos napok előfordulásában és gyakoriságában megfigyelhető növekedéssel párhuzamosan.

A Pó-síkságon és a környező térségben megfigyelt csapadékösszeg-csökkenés az egész mediterrán térségben kutatott jelenség. Például Norrant \& Douguédroit (2006) a csapadékos helyzetek csökkenő trendjét mutatta ki, azonban a változások általában nem bizonyultak szignifikánsnak pár izolált terület kivételével. A tanulmány a $10 \mathrm{~mm}$-t meghaladó csapadékú napok csökkenésére hívta fel figyelmet, ugyanakkor az extrém csapadékos események intenzitása növekedett.

Összességében elmondható, hogy habár a csapadékmezők általános változásaiban különböznek egymástól a térségek, mind a három esetben növekedett az extrém csapadékos helyzetek előfordulása, intenzitása. Tehát a csapadékkal kapcsolatos természeti kockázatok nőttek, ugyanakkor a Pó-síkság és a Pannon-alföld térségét a csapadék hiányához köthető száraz időszakok gyakoriságának és hosszának növekedése is veszélyeztetheti, amely komoly környezeti és gazdasági következményekkel járhat.

\section{Köszönetnyilvánítás}

Kutatásainkat támogatta a Nemzeti Kutatási, Fejlesztési és Innovációs Alap K-129162 és K 120605 számú projektje, valamint az Emberi Erőforrások Minisztériuma az ELTE Tématerületi Kiválósági Program 2020 - Intézményi Kiválósági Alprogram - (TKP2020IKA-05) keretében.

\section{Hivatkozások}

Bartholy, J., Pongrácz, R., 2007: Regional analysis of extreme temperature and precipitation indices for the Carpathian Basin from 1946 to 2001. Global and Planetary Change, 57: 83-95. https://doi.org/10.1016/j.gloplacha.2006.11.002

Cornes, R.C., van der Schrier, G., van den Besselaar, E.J.M., Jones, P.D., 2018: An Ensemble Version of the E-OBS Temperature and Precipitation Data Sets. Journal of Geophysical Research: Atmospheres, 123: 9391-9409. https://doi.org/10.1029/2017JD028200

Croitoru, A.-E., Piticar, A., Burada, D.C., 2015: Changes in precipitation extremes in Romania. Quaternary International, 415: 325-335. http://dx.doi.org/10.1016/j.quaint.2015.07.028

Jacob, D., Petersen, J., Eggert, B., Alias, A., Christensen, O.B., Bouwer, L.M., Braun, A., Colette, A., Déqué, M., Georgievski, G., Georgopoulou, E., Gobiet, A., Menut, L., Nikulin, G., Haensler, A., Hempelmann, N., Jones, C., Keuler, K., Kovats, S., Kröner, N., Kotlarski, S., Kriegsmann, A., Martin, E., van Meijgaard, E., Moseley, C., Pfeifer, S., Preuschmann, S., Radermacher, C., Radtke, K., Rechid, D., Rounsevell, M., Samuelsson, P., Somot, S., Soussana, J.F., Teichmann, C., Valentini, R., Vautard, R., Weber, B., Yiou, P., 2014: EURO-CORDEX: new high-resolution 
climate change projections for European impact research. Regional Environmental Change, 14: 563-578. https://doi.org/10.1007/s10113-013-0499-2

Klein Tank, A.M., G., Können, G.P., 2003: Trends in Indices of Daily Temperature and Precipitation Extremes in Europe, 1946-99. Journal of Climate, 16: 3665-3680. https://doi.org/10.1175/1520-0442(2003)016<3665:TIIODT>2.0.CO;2.

Messmer, M., Gómez-Navarro., J.J., Raible, C.C., 2015: Climatology of Vb Cyclones, physical mechanism and their impact on extreme precipitation over Central Europe. Earth System Dynamics, 6: 541-553. https://doi.org/10.5194/esd-6-541-2015

Norrant, C., Douguédroit, A., 2006: Monthly and daily precipitation trends in the Mediterranean (1950-2000). Theoretical and Applied Climatology. 83: 89-106. https://doi.org/10.1007/s00704005-0163-y

Peterson, T.C., Folland, C., Gruza, G., Hogg, W., Mokssit, A., Plummer, N., 2001: Report on the Activities of the Working Group on Climate Change Detection and Related Rapporteurs 19982001. WMO, Rep. WCDMP-47, WMO-TD 1071, Geneve, Switzerland, 143p.

Rajczak, J., Schär, C., 2017: Projections of future precipitation extremes over Europe: A multimodel assessment of climate simulations. Journal of Geophysical Research: Atmospheres, 122: 10,773-10,800. https://doi.org/10.1002/2017JD027176

Spinoni, J., Naumann, G., Vogt, J.V., 2017: Pan-European seasonal trends and recent changes of drought frequency and severity. Global and Planetary Change, 148: 113-130. http://dx.doi.org/10.1016/j.gloplacha.2016.11.013

Zolina, O., Simmer, C., Belyaev, K., Gulev, S.K., Koltermann, P., 2013: Changes in the Duration of European Wet and Dry Spells during the Last 60 Years. Journal of Climate, 26: 2022-2047. https://doi.org/10.1175/JCLI-D-11-00498.1.

\section{ORCID}

Berényi A. (D) https://orcid.org/0000-0002-5985-0531

Pongrácz R. (D) https://orcid.org/0000-0001-7591-7989

Bartholy J. (D) https://orcid.org/0000-0002-3911-7981 